University of the Pacific

Scholarly Commons

3-1-1993

\title{
A Common Mechanism for Influenza Virus Fusion Activity and Inactivation
}

\author{
João Ramalho-Santos \\ University of Coimbra, Center for Neuroscience and Cell Biology \\ Shlomo Nir \\ University of the Pacific, California \\ Nejat Düzgüneş \\ University of the Pacific, California, nduzgunes@pacific.edu \\ Arsélio Pato de Carvalho \\ University of Coimbra, Center for Neuroscience and Cell Biology \\ Maria Conceição Pedroso De Lima \\ University of Coimbra, Center for Neuroscience and Cell Biology
}

Follow this and additional works at: https://scholarlycommons.pacific.edu/dugoni-facarticles

Part of the Dentistry Commons

\section{Recommended Citation}

Ramalho-Santos, J., Nir, S., Düzgüneş, N., de Carvalho, A. P., \& De Lima, M. C. (1993). A Common

Mechanism for Influenza Virus Fusion Activity and Inactivation. Biochemistry, 32(11), 2771-2779. DOI:

10.1021/bi00062a006

https://scholarlycommons.pacific.edu/dugoni-facarticles/560

This Article is brought to you for free and open access by the All Faculty Scholarship at Scholarly Commons. It has been accepted for inclusion in All Dugoni School of Dentistry Faculty Articles by an authorized administrator of Scholarly Commons. For more information, please contact mgibney@pacific.edu. 


\title{
A Common Mechanism for Influenza Virus Fusion Activity and Inactivation ${ }^{\dagger}$
}

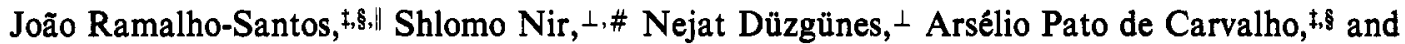 \\ Maria da Conceição Pedroso de Lima*,+,\|,o \\ Center for Cell Biology and Center for Neurosciences of Coimbra, Zoology Department, Biochemistry Department, and \\ Laboratory of Biochemistry, Faculty of Medicine, University of Coimbra, 3049 Coimbra Codex, Portugal, and Department of \\ Microbiology, School of Dentistry, University of the Pacific, San Francisco, California 94115-2399
}

Received October 27, 1992; Revised Manuscript Received January 4, 1993

\begin{abstract}
The fusion of influenza virus (A/PR/8/34 strain) with PC-12 cells was monitored by a fluorescence assay, and the results were analyzed with a mass-action model which could explain and predict the kinetics of fusion. The model accounted explicitly for the reduction in the fusion rate constant upon exposure of the virus to low $\mathrm{pH}$, either for the virus alone in suspension or for the virus bound to the cells. When the $\mathrm{pH}$ was lowered without previous viral attachment to cells, an optimal fusion activity was detected at $\mathrm{pH}$ 5.2. When the virus was prebound to the cells, however, reduction of $\mathrm{pH}$ below 5.2 resulted in enhanced fusion activity at the initial stages. These results were explained by the fact that the rate constants of both fusion and inactivation increased severalfold at $\mathrm{pH} 4.5$ or 4, compared to those at $\mathrm{pH} 5.2$. At $\mathrm{pH} 5.2$, lowering the temperature from 37 to 20 or $4^{\circ} \mathrm{C}$ resulted in a decrease in the fusion rate constant by more than 30- or 1000-fold, respectively. Inactivation of the virus when preincubated in the absence of target membranes at $\mathrm{pH} 5$ was found to be rapid and extensive at $37^{\circ} \mathrm{C}$, but was also detected at $0{ }^{\circ} \mathrm{C}$. Our results indicate a strong correlation between fusion and inactivation rate constants, suggesting that the rate-limiting step in viral hemagglutinin (HA)-mediated fusion, that is, rearrangement of viral glycoproteins at the contact points with the target membrane, is similar to that involved in fusion inactivation.
\end{abstract}

Although the cell entry routes of various lipid-enveloped viruses and the envelope proteins that mediate cell attachment and entry have been identified (March \& Helenius, 1989; White, 1990), the molecular mechanisms by which these proteins induce the fusion of viral and cellular membrane are not known in detail. The hemagglutinin (HA) ${ }^{1}$ of influenza virus is the only viral envelope protein for which detailed structural information is available (Skehel et al., 1982). Since influenza virus is induced to fuse with target membranes at low $\mathrm{pH}(\approx 5)$, the conformational changes of $\mathrm{HA}$ at low $\mathrm{pH}$ have been studied by enzyme susceptibility, circular dichroism, electron microscopy, and antibody reactivity (Skehel et al., 1982; Ruigrok et al., 1986; Wharton et al., 1986; White \& Wilson, 1987). These studies have provided insights into the mechanisms by which the protein might cause membrane fusion. For example, the low-pH-mediated exposure of the N-terminal hydrophobic peptide of the HA2 subunit (Skehel et al., 1982) and the unfolding of the HA trimer (Doms \& Helenius, 1986; White \& Wilson, 1987) have been associated with the fusion activity of the protein. A possible drawback

+ This work was supported by INIC and JNICT, Portugal, by NATO Collaborative Research Grant CRG 900333 (M.C.P.L. and N.D.), and by Grant AI-25534 from the National Institute of Allergy and Infectious Diseases (N.D. and S.N.).

* Correspondence should be addressed to this author at the Center for Cell Biology, University of Coimbra, 3049 Coimbra Codex, Portugal. Telephone: 351 (39) 34729. Fax: 351 (39) 35812.

‡ Center for Cell Biology and Center for Neurosciences of Coimbra, University of Coimbra.

$\S$ Zoology Department, University of Coimbra.

4 Laboratory of Biochemistry, Faculty of Medicine, University of Coimbra.

$\perp$ Department of Microbiology, University of the Pacific.

\# On sabbatical leave from the Seagram Center for Soil and Water Sciences, Faculty of Agriculture, The Hebrew University of Jerusalem, Rehovot 76100, Israel

- Biochemistry Department, University of Coimbra.

${ }_{1}^{1}$ Abbreviations: R18, octadecylrhodamine B chloride; $\mathrm{C}_{12} \mathrm{E}_{8}$, octaethylene glycol dodecyl ether; $\mathrm{HA}$, influenza virus hemagglutinin. in the interpretation of these conformational changes is that the latter have been based primarily on the behavior of the water-soluble ectodomain of $\mathrm{HA}$ obtained by bromelain treatment of viral HA (Doms et al., 1985; Ruigrok et al., 1986; Wharton et al., 1986; White \& Wilson, 1987). However, the association between HA trimers in the viral membrane may contribute to fusion (Morris et al., 1989; Sarkar et al., 1989; Ellens et al., 1990) and to the inactivation of the fusion activity (Junankar \& Cherry, 1986). Inactivation is caused by exposure of the virus to low $\mathrm{pH}$ in the absence of target membranes with which the virus can fuse (Sato et al., 1983; Stegmann et al., 1986), and is thought to be due to clustering of the conformationally altered HA trimers (Junankar \& Cherry, 1986). By studying the very slow fusion of influenza virus with liposomes and erythrocyte ghosts in the cold, Stegmann et al. (1990) have proposed that fusion can occur without unfolding of the trimers and that the unfolding may lead to inactivation in the fusion capacity of the virus. This proposal was based on their observation that the virus was not inactivated by low-pH treatment in the cold.

Using a mass-action kinetic analysis of virus-cell fusion, we have quantitated the low-pH inactivation of influenza virus (A/PR/8/34 strain) (Nir et al., 1988; 1990; Düzgünes et al., 1992) and found that even the virions bound to the cell surface can undergo some inactivation. We have also observed that the virus preincubated at low pH and $37^{\circ} \mathrm{C}$ is only partially inactivated in its ability to fuse with HL-60 and CEM cells (Düzgünes et al., 1992). Our observations reported here indicate, however, that appreciable and fast inactivation of fusion capacity is indeed observed with other cultured cells, such as PC- 12 cells, as target membranes. We have analyzed the fusion and inactivation processes as a function of $\mathrm{pH}$ and temperature and have found correlations between the fusion and inactivation rate contants. Guided by this analysis, we have designed experiments which demonstrated that low-pH inactivation does occur in the cold, in contrast to the 
observations of Stegmann et al. (1990). Our results suggest the hypothesis that the rate-limiting step in the fusion of influenza virus (prebound to cells before the induction of fusion) depends on the same process that leads to inactivation.

\section{EXPERIMENTAL PROCEDURES}

Virus. Influenza virus, A/PR/8/34 (H1N1) strain, was grown for $48 \mathrm{~h}$ at $37^{\circ} \mathrm{C}$ in the allantoic cavity of 11-day-old embryonated eggs, purified by discontinuous sucrose density gradient centrifugation, and stored at $-70^{\circ} \mathrm{C}$ in phosphatebuffered saline.

Cells. PC- 12 cells were obtained from the American Type Culture Collection (ATCC), Rockville, MD. The cells were grown in RPMI 1640 medium containing $25 \mathrm{mM}$ Hepes buffer, supplemented with $10 \%$ fetal bovine serum and $5 \%$ heatinactivated horse serum. The cells were grown in T-75 flasks up to a cell density of $(1-1.5) \times 10^{6} / \mathrm{mL}$ under a $5 \% \mathrm{CO}_{2}$ atmosphere in a Forma Scientific incubator. The cells were harvested by centrifugation at $180 \mathrm{~g}$ for $8 \mathrm{~min}$ at room temperature, washed twice in phenol red-free RPMI 1640 supplemented with $25 \mathrm{mM}$ Hepes buffer, and resuspended in a saline buffer containing $130 \mathrm{mM} \mathrm{NaCl}, 5 \mathrm{mM} \mathrm{KCl}, 2 \mathrm{mM}$ $\mathrm{CaCl}_{2}, 1 \mathrm{mM} \mathrm{MgCl}_{2}, 10 \mathrm{mM}$ glucose, and $15 \mathrm{mM}$ Hepes, $\mathrm{pH}$ 7.4 .

The cells, which form clusters, were dispersed by several passages through a 22-gauge syringe and then counted in a hemocytometer. Cell viability was determined by trypan blue exclusion and was routinely above $90 \%$. This viability remained constant throught the experiments. The cells were then transferred to quartz fluorometer cuvettes in the desired final density. Cell-cell aggregation was avoided by continuous stirring.

The median PC-12 cell diameter averaged $14 \mu \mathrm{m}$, as described before (Lima et al., 1992).

Virus Labeling. The virus was labeled with octadecylrhodamine B chloride (R18, Molecular Probes Inc., Eugene, $\mathrm{OR}$ ) as described previously (Hoekstra et al., 1984). A 4.8$\mu \mathrm{L}$ aliquot of a $3.12 \mu \mathrm{mol} / \mathrm{mL}$ ethanolic fluorophore solution was injected under vortex mixing into a viral suspension containing $2 \mathrm{mg}$ of viral protein $/ \mathrm{mL}$. The final concentration of added probe corresponds to approximately $4 \mathrm{~mol} \%$ of total viral lipid, and that of ethanol was less than $1 \%(\mathrm{v} / \mathrm{v})$. The mixture was incubated in the dark for $0.5-1 \mathrm{~h}$ at room temperature. R18-labeled virus was separated from noninserted fluorophore by chromatography on Sephadex G-75 (Pharmacia, Uppsala, Sweden) using $150 \mathrm{mM} \mathrm{NaCl} / 10 \mathrm{mM}$ Tes, $\mathrm{pH} 7.4$, as elution buffer. The protein concentration of the labeled virus was determined by the Lowry assay.

Fusion of R18-Labeled Influenza Virus with PC-12 Cells. Fusion, monitored continuously with the fluorescence assay as described elsewhere (Hoekstra et al., 1984, 1985), was initiated by rapid injection of $R 18$-labeled virus into a cuvette containing the cell suspension $\left(5 \times 10^{6}\right.$ cells). Adjustments in the experimental $\mathrm{pH}$ were carried out as described under Results. The final incubation volume was always $2 \mathrm{~mL}$. The fluorescence scale was calibrated such that the initial fluorescence of R18-labeled virus and cell suspension was set at $0 \%$ fluorescence. The value obtained by lysing the virus and cellular membranes after each experiment with $\mathrm{C}_{12} \mathrm{E}_{8}$ (Calbiochem, San Diego, CA), at a final concentration of 3.15 $\mathrm{mM}$, was set at $100 \%$ fluorescence.

Fluorescence measurements were performed in a PerkinElmer LS-50 luminescence spectrometer with excitation at $560 \mathrm{~nm}$ and emission at $590 \mathrm{~nm}$, using 5- and $20-\mathrm{nm}$ slits, respectively, in the excitation and emission monochromators.
The sample chamber was equipped with a magnetic stirring device, and the temperature was controlled with a thermostated circulating water bath.

Cell Association. Fluorescently labeled influenza virus (1 $\mu \mathrm{g}$ of viral protein $/ \mathrm{mL}$ ) was incubated with PC- 12 cells $(5 \times$ $10^{6}$ cells) in a final volume of $2 \mathrm{~mL}$ of saline buffer (see above) with continuous stirring. Incubations were carried out at $37^{\circ} \mathrm{C}$ and different $\mathrm{pH}$ values (see Results). Mixtures were then transferred to polypropylenes tubes and centrifuged at $37^{\circ} \mathrm{C}$ for $8 \mathrm{~min}$ at $180 \mathrm{~g}$. Fluorescence was measured in the pellet and the supernatant after the addition of $\mathrm{C}_{12} \mathrm{E}_{8}$ $(3.15 \mathrm{mM})$ to determine the fraction of cell-associated virus and free virus, respectively.

Enzymatic Treatment. For proteinase $\mathrm{K}$ treatment, $2 \mu \mathrm{g}$ of viral protein was incubated for $30 \mathrm{~min}$ at $37^{\circ} \mathrm{C}$ and $\mathrm{pH}$ 5.0 at a final enzyme concentration of $0.05 \mathrm{mg} / \mathrm{mL}$. Following this incubation, the virus was added to the fluorometer cuvette containing $5 \times 10^{6}$ cells at $37^{\circ} \mathrm{C}$. In the fusion experiments, the proteinase $\mathrm{K}$ concentration was reduced 20 -fold.

Other Procedures. PC- 12 cells $\left(5 \times 10^{6}\right.$ cells) were incubated with $1 \%(\mathrm{w} / \mathrm{v})$ sodium azide for $30 \mathrm{~min}$ at $37^{\circ} \mathrm{C}$ (in a total volume of $1.9 \mathrm{~mL}$ ) with continuous stirring. This procedure has been described to reduce cell endocytic activity (Blumenthal et al., 1987). Incubation of PC- 12 cells $\left(5 \times 10^{6}\right.$ cells) with either 30 to $100 \mathrm{mM} \mathrm{NH} \mathrm{Cl}_{4}$ or with $6-12 \mu \mathrm{M}$ monensin $\left(15 \mathrm{~min}, 37^{\circ} \mathrm{C}\right.$, total volume $1.9 \mathrm{~mL}$, and continuous stirring) was carried out to increase the $\mathrm{pH}$ in intracellular acidic compartments (Mellman et al., 1986; Stegmann et al., 1987b). Following the incubations, labeled influenza virus ( $2 \mu \mathrm{g}$ of viral protein) was added to the cells, and fusion was monitored ( $\mathrm{pH} 7.4,37^{\circ} \mathrm{C}$ ) as described above.

Analysis of Fusion Kinetics. We have explicitly taken into account that the fusion activity of influenza virus exposed to low $\mathrm{pH}$ is reduced with time of exposure. According to Nir et al. (1988), the expression for the fusion rate constant, $f$ $\left(\mathrm{s}^{-1}\right)$, that accounts for inactivation is given by

$$
f(t)=f(0)\left\{\exp (-\gamma t)+\gamma_{2}[1-\exp (-\gamma t) / \gamma]\right\}
$$

in which $\gamma=\gamma_{1}+\gamma_{2}$. In eq $1 \gamma_{1}$ and $\gamma_{2}$ represent forward and reverse rate constants of inactivation, respectively. Equation 1 indicates that a residual fusion activity is retained even after a long period of inactivation:

$$
f=f(0) \gamma_{2} / \gamma
$$

(i) Prebinding Experiments. Here the virus is first prebound to the cells at neutral $\mathrm{pH}$ for several minutes, and $B$, the fraction of virus bound, is measured. Fusion is initiated by lowering the $\mathrm{pH}$. If $B$ is assumed to remain constant during the fusion period, then the fraction of virus fused is given by

$$
\begin{aligned}
F(t)=\left\{1-\exp \left[f ( 0 ) \left[\left(\gamma_{1} / \gamma^{2}\right) \exp (-\gamma t)-\right.\right.\right. \\
\left.\left.\left.\left(\gamma_{2} / \gamma\right) t-\gamma_{1} / \gamma^{2}\right]\right]\right\} B
\end{aligned}
$$

This equation includes three parameters: $f$ or $f(0), \gamma_{1}$, and $\gamma_{2}$. However, the effect of $\gamma_{2}$ is noticed only at later times, since $\gamma_{2} \ll \gamma_{1}$. Furthermore, during the first few seconds, the effect of inactivation is ordinarily small, which means that $F(t)$ in eq 3 can be approximated by

$$
F(t)=[1-\exp (-f t)] B
$$

from which $f$ can be determined. Hence, the parameters $f$, $\gamma_{1}$, and $\gamma_{2}$ can be sequentially determined and then refined by considering the overall fit.

We introduced a small correction by also measuring $B$ after several minutes (usually $10 \mathrm{~min}$ ) of fusion, and assuming the increase of $B$ during the fusion period was linear. Typically, 


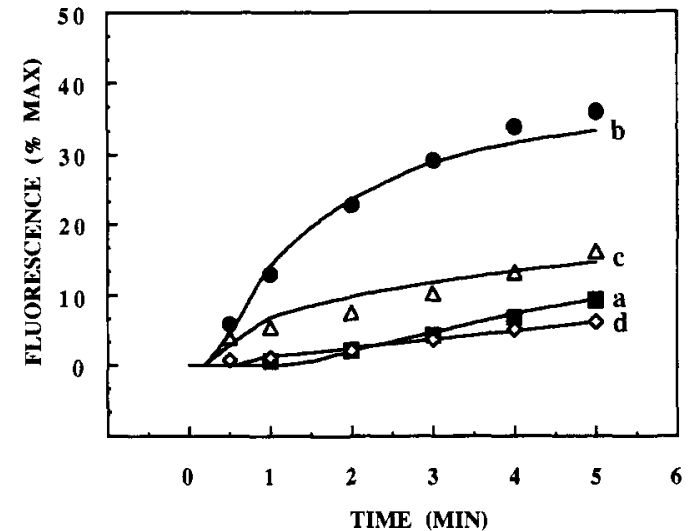

FIGURE 1: $\mathrm{pH}$ effect on influenza virus fusion activity toward PC-12 cells in the absence of viral prebinding. Influenza virus $(1 \mu \mathrm{g} / \mathrm{mL}$ viral protein) was added to $5 \times 10^{6} \mathrm{PC}-12$ cells in a final volume of $2 \mathrm{~mL}$, and $\mathrm{R} 18$ dequenching was monitored for $5 \mathrm{~min}$ at $37^{\circ} \mathrm{C}$. The $\mathrm{pH}$ of the cell suspension was adjusted previously to $5.8(\mathrm{a}), 5.2(\mathrm{~b})$, 4.5 (c), and 4.0 (d). The values calculated with the parameters shown in Table I are also presented for $\mathrm{pH} 5.8(\square), 5.2(\bullet), 4.5(\Delta)$, and $4.0(0)$.

$B$ values increased from 0.4 to 0.5 during $10 \mathrm{~min}$, which amounts to increasing $B$ from 0.4 to 0.41 after 1 min etc. In eq 3 , it is implicitly assumed that all the virions are capable of fusing. This was indeed observed in the fusion of influenza virus with PC- 12 cells at $\mathrm{pH} 5.2$. Alternatively, $F$ in eq 3 should indicate a fraction of the virus population that is capable of fusing. The inactivation of the virus that is bound to the cells may differ from that of the virus in suspension. Experimentally, we have tested this possibility by preincubating the virus alone at low $\mathrm{pH}$, then returning the $\mathrm{pH}$ to neutral, and preincubating the virus with the cells at neutral $\mathrm{pH}$. From the reduction of $f$, or $f(0)$, as a function of the time of this inactivation, we can determine $\gamma_{1}$ and $\gamma_{2}$ by applying eq 1 .

(ii) No Prebinding. In these experiments, the virus is added to the cells at the given $\mathrm{pH}$. The kinetic analysis employs the following parameters: $C\left(\mathrm{M}^{-1} \cdot \mathrm{s}^{-1}\right)$, the rate constant of viral adhesion to the cells; $f\left(\mathrm{~s}^{-1}\right)$, the rate constant of the actual fusion of an adhered virus particle; $D\left(\mathrm{~s}^{-1}\right)$, the dissociation rate constant (Nir et al., 1986b). The analysis also considers the reduction of the rate constant of fusion with time, according to eq 1 (Nir et al., 1990). Initially, dissociation, as well as inactivation, plays a minor role, which enables determination of $C$ and $f$. Since this procedure employs five parameters, it is difficult to fit the data $a b$ initio. Thus, the main purpose of the analysis of these experiments was to test the ability of the model to simulate the kinetics with parameters consistent with those found from prebinding experiments.

\section{RESULTS}

Dependence of Viral Fusion Activity on Viral Prebinding to Cells. Two different experimental approaches were used to determine the effect of $\mathrm{pH}$ on influenza virus fusion activity toward $\mathrm{PC}-12$ cells at $37^{\circ} \mathrm{C}$. When influenza virus was added directly to a cell suspension already adjusted to the desired $\mathrm{pH}$, the fusion activity (as monitored by $\mathrm{R} 18$ dequenching) was optimal at pH 5.2 (Figure 1), virus-cell fusion being lower at $\mathrm{pH}$ values below 5.2. A short lag phase, prior to measurable dequenching, was detected in all the experiments. This delay could be attributed to either virus-cell binding and/or conformational changes required to activate the virions at low $\mathrm{pH}$ (see below). When parallel experiments were carried out with virus already bound to the cells at neutral $\mathrm{pH}$, the results were markedly different (Figure 2 ). Here, the initial

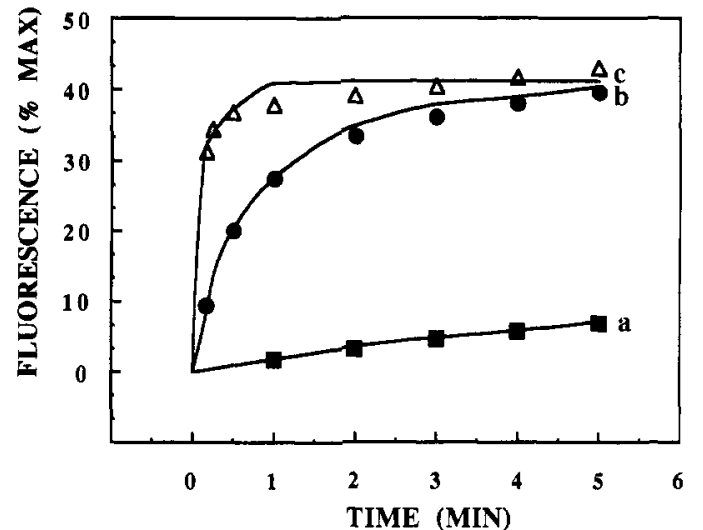

FIGURE 2: $\mathrm{pH}$ effect on influenza virus fusion activity toward PC-12 cells in the presence of viral prebinding. Influenza virus $(1 \mu \mathrm{g} / \mathrm{mL}$ viral protein) was added to $5 \times 10^{6} \mathrm{PC}-12$ cells in a final volume of $2 \mathrm{~mL}$ at $37^{\circ} \mathrm{C}$ and $\mathrm{pH} 7.4$. After $5 \mathrm{~min}$, the $\mathrm{pH}$ was lowered to 5.8 (a), 5.2 (b), and 4.5 (c), and R18 dequenching was monitored for $5 \mathrm{~min}$. When the $\mathrm{pH}$ was adjusted to 4.0 , the dequenching was only slightly quicker and more extensive than the one obtained at $\mathrm{pH} 4.5$ (not shown, see Table I). The values calculated with the parameters shown in Table II are also presented for pH $5.8(\square), 5.2(\bullet)$, and $4.5(\Delta)$.

rate and extent of fusion were higher than in experiments without prebinding. Although the existence of prebinding could account for the increased initial kinetics and extent of fusion observed for all $\mathrm{pH}$ values, it was interesting to note that, in this case, acidification below pH 5.2 did not result in any decrease in fusion activity. In fact, at $\mathrm{pH} 4.5$, the extent of dequenching after $1 \mathrm{~min}$ was significantly larger than at pH 5.2, whereas after $5 \mathrm{~min}$ the extents were similar. These results may be explained by the kinetic analysis, which invokes an increase in the fusion $(f)$ and inactivation $(\gamma)$ rate constants with decreasing $\mathrm{pH}$ (see Tables I and II). These results also suggest that the lag phase observed without prebinding is mostly due to the time it takes for the virus to bind to the cells, since it could not be detected when prebinding took place.

It should be noted that upon incubation of the virus with the cells at pH 7.4 only a slight amount of $\mathrm{R} 18$ dequenching was observed (not shown, see Table III). In fact, very little dequenching was observed at $\mathrm{pH}$ values from 6.4 up to 9.0, either with or withour viral-cell binding (not shown).

Temperature Dependence of Viral Fusion Activity. In experiments carried out in the absence of prebinding, viral fusion activity was very low at temperatures below $20^{\circ} \mathrm{C}$, probably due to a lack of mobility in the viral glycoproteins (Junankar \& Cherry, 1986; Brunner et al., 1991). A decrease in temperature also involved an increase in the lag time observed. Above $20^{\circ} \mathrm{C}$, the fusion activity increased steadily as the temperature approached $37^{\circ} \mathrm{C}$ (not shown). At 20 ${ }^{\circ} \mathrm{C}$, even with viral-cell prebinding, a short but distinct lag was detected before the onset of fusion (Figure 6, curve a). However, at $4^{\circ} \mathrm{C}$, the lag time was of $5 \mathrm{~min}$ (see Table II). This lag is most likely due to a delay in viral glycoprotein conformational changes and rearrangements which are very rapid at $37^{\circ} \mathrm{C}$ (no lag being detected at this temperature, see above) but are much slower at lower temperatures (Junankar \& Cherry, 1986; Stegmann et al., 1990).

Viral Inactivation. We have quantitated the inactivation of influenza virus at low $\mathrm{pH}$ by incubating the virus at $\mathrm{pH} 5$ in the absence of the target membrane for different times and at various temperatures. The fusion activity of the low-pHpretreated virus was then determined at $\mathrm{pH} 5.2$ and $37^{\circ} \mathrm{C}$, either with (Figure 4) or without (Figure 3) virus-cell prebinding at $\mathrm{pH} 7.4$. 
Table I: Parameters Describing Fusion Activity of Influenza Virus in the Absence of Viral-Cell Prebinding: pH Effect and Viral Inactivation

\begin{tabular}{|c|c|c|c|c|c|c|}
\hline \multirow[b]{2}{*}{ condn } & \multirow[b]{2}{*}{$\mathrm{pH}$} & \multirow{2}{*}{$\begin{array}{c}\text { adhesion rate } \\
\text { constant, } C\left(\mathrm{M}^{-1} \cdot \mathrm{s}^{-1}\right)\end{array}$} & \multirow{2}{*}{$\begin{array}{l}\text { dissociation rate } \\
\text { constant, } D\left(\mathrm{~s}^{-1}\right)\end{array}$} & \multirow{2}{*}{$\begin{array}{c}\text { fusion rate } \\
\text { constant, } f\left(\mathrm{~s}^{-1}\right)\end{array}$} & \multicolumn{2}{|c|}{$\begin{array}{l}\text { forward }\left(\gamma_{1}\right) \text { and reverse }\left(\gamma_{2}\right) \\
\text { rate constants of low-pH inactn }\end{array}$} \\
\hline & & & & & $\gamma_{1}\left(\mathrm{~s}^{-1}\right)$ & $\gamma_{2}\left(\mathrm{~s}^{-1}\right)$ \\
\hline effect of pH at $37^{\circ} \mathrm{C}$ & $\begin{array}{l}4 \\
4.5 \\
5.2 \\
5.8 \\
7.4\end{array}$ & $\begin{array}{l}3.5 \times 10^{11} \\
3.8 \times 10^{11} \\
(3.5-5.5) \times 10^{11} \\
3.5 \times 10^{11} \\
\geq 2 \times 10^{11}\end{array}$ & $\begin{array}{l}0.004 \\
0.005 \\
0.004 \\
0.002\end{array}$ & $\begin{array}{l}0.3 \\
0.3 \\
0.035-0.07 \\
0.0014\end{array}$ & $\begin{array}{l}0.3( \pm 0.02) \\
0.1 \\
0.018-0.026 \\
0.002\end{array}$ & $\begin{array}{l}0.001( \pm 0.0005) \\
0.0008 \\
0.001-0.002 \\
0.001\end{array}$ \\
\hline $\begin{array}{l}\text { effect of preincubn of virus alone } \\
\text { for } 1 \text { min at } \mathrm{pH} 5 \text { and } 37^{\circ} \mathrm{C}\end{array}$ & 5.2 & & & 0.004 & 0.025 & 0.002 \\
\hline
\end{tabular}

"See eq 1 . The rate constants, $\gamma_{1}$ and $\gamma_{2}$, in the table refer to forward and reverse inactivation, respectively, and reflect effective values for unbound as well as bound virus. The estimated uncertainties in the parameters are $f(25 \%), \gamma_{1}(20 \%), \gamma_{2}(50 \%), \gamma_{1} / \gamma_{2}(10 \%), C(20 \%)$, and $D(50 \%)$, unless a range is indicated.

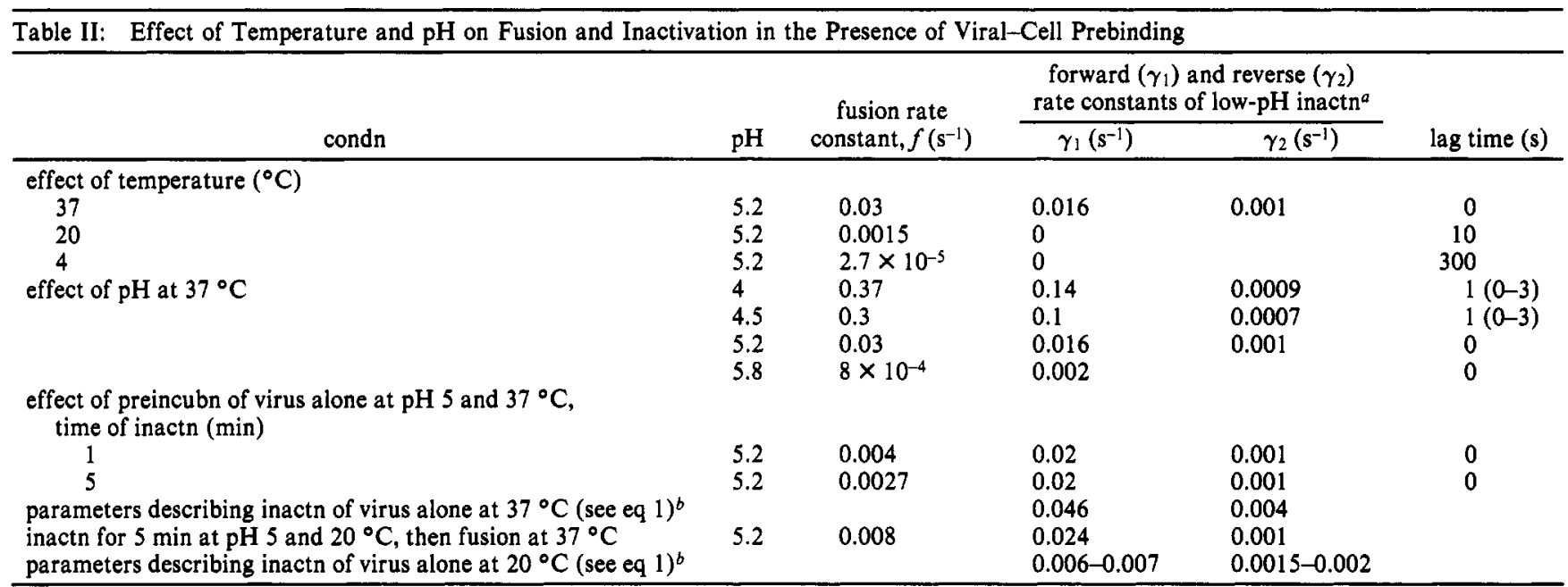

${ }^{a}$ See eq 1 . The rate constants, $\gamma_{1}$ and $\gamma_{2}$, in the table refer to forward and reverse inactivation, respectively, for the virus bound to the cells. ${ }^{b}$ In this case, $\gamma_{1}$ and $\gamma_{2}$ (see eq 1) describe inactivation of the virus alone (in the absence of target membranes). The estimated uncertainties in the parameters are $f(25 \%), \gamma_{1}(20 \%), \gamma_{2}(50 \%)$, and lag time $(20 \%)$, unless a range is indicated.

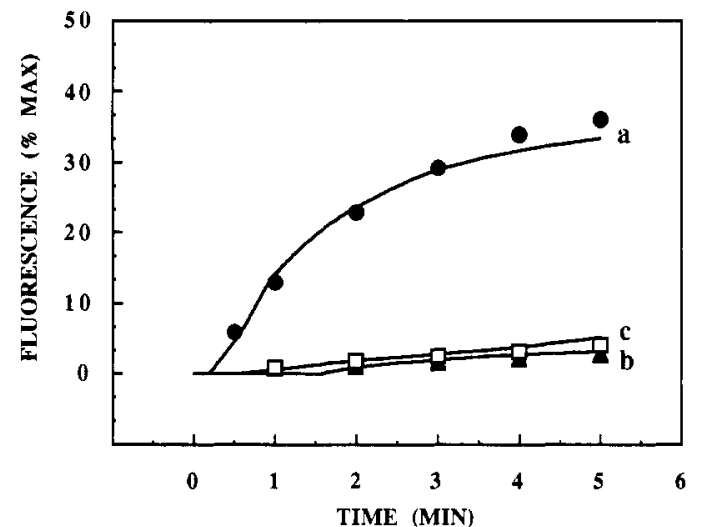

FIGURE 3: Inactivation of influenza virus assessed in the absence of viral prebinding. The virus was incubated at $\mathrm{pH} 5.0$ in the absence of the target membrane for various times and at different temperatures. The fusion activity of the preincubated virions was monitored for $5 \mathrm{~min}$ at $\mathrm{pH} 5.2$ and $37^{\circ} \mathrm{C}$, following addition of $1 \mu \mathrm{g} / \mathrm{mL}$ viral protein to $5 \times 10^{6} \mathrm{PC}-12$ cells (final volume $2 \mathrm{~mL}$ ). (a) Control (no preincubation). (b) Virus preincubated for $1 \mathrm{~min}$ at $37^{\circ} \mathrm{C}$. (c) Virus preincubated for $5 \mathrm{~min}$ at $20^{\circ} \mathrm{C}$. The values calculated with the parameters shown in Table I are also presented for a $(\bullet), b(\Delta)$, and $\mathrm{c}(\square)$. Viral preincubation for $1 \mathrm{~min}$ at $20^{\circ} \mathrm{C}$ or for $20 \mathrm{~min}$ on ice did not result in any change in fusion activity (not shown).

When the virus was incubated at $\mathrm{pH} 5.0$ and $37^{\circ} \mathrm{C}$, inactivation was rapid and extensive, whether fusion was assayed with (Figure 4, curve b) or without (Figure 3 curve b) prebinding. However, in both cases, the virus maintained a residual fusion activity that could not be significantly reduced by increasing the preincubation time up to $30 \mathrm{~min}$. Inactivation

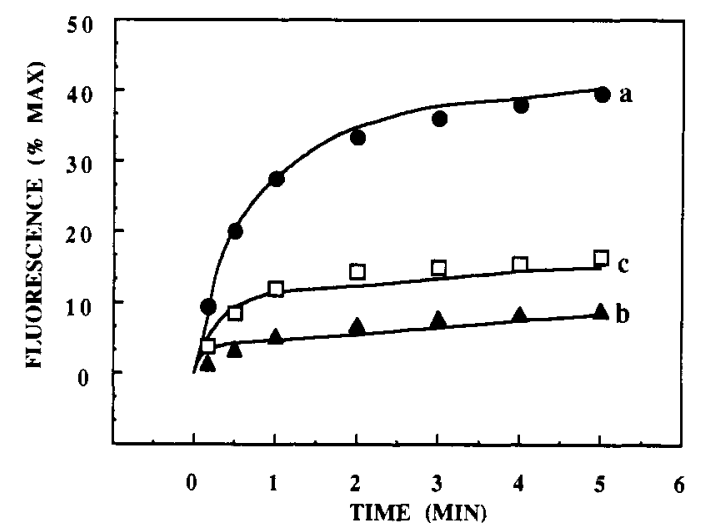

FIGURE 4: Inactivation of influenza virus assessed in the presence of viral prebinding. The virus was incubated at $\mathrm{pH} 5$ in the absence of the target membrane for various times and at different temperatures. The fusion activity of the preincubated virions was monitored by adding $1 \mu \mathrm{g} / \mathrm{mL}$ viral protein $5 \times 10^{6} \mathrm{PC}-12$ cells (final volume $2 \mathrm{~mL}$ ) at $\mathrm{pH} 7.4$ and $37^{\circ} \mathrm{C}$. After $5 \mathrm{~min}$, the $\mathrm{pH}$ was lowered to 5.2 and R 18 dequenching was followed for 5 min. (a) Control (no preincubation). (b) Virus preincubated for $1 \mathrm{~min}$ at $37^{\circ} \mathrm{C}$. (c) Virus preincubated for $5 \mathrm{~min}$ at $20^{\circ} \mathrm{C}$. The values calculated with the parameters shown in Table II are also presented for a $(\bullet), b(\boldsymbol{\Delta})$, and $c(\square)$. Viral preincubation for $30 \mathrm{~min}$ at $20^{\circ} \mathrm{C}$ resulted in similar activity as that registered for 1 -min preincubation at $37^{\circ} \mathrm{C}$ (not shown). Viral preincubation for $1 \mathrm{~min}$ at $20^{\circ} \mathrm{C}$ or for $30 \mathrm{~min}$ on ice did not result in any change in fusion activity (not shown).

of the virus for 30 min gave similar results to those obtained following $5 \mathrm{~min}$ of inactivation (not shown).

Inactivation of influenza virus was temperature-dependent, being reduced extensively with low-pH preincubations carried 


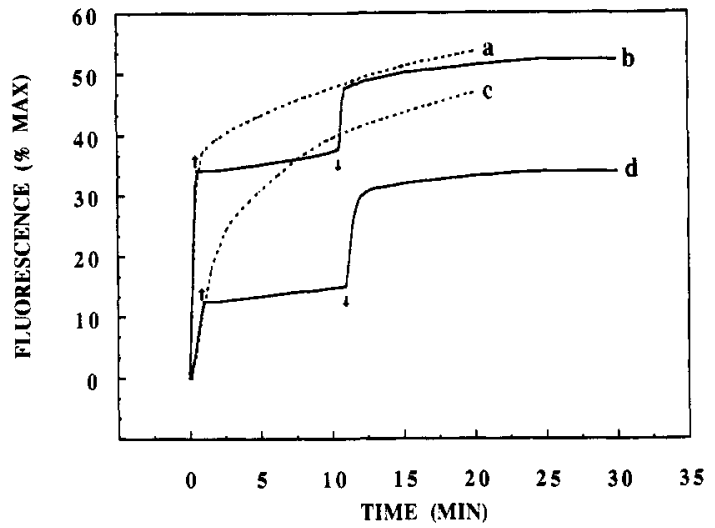

FIGURE 5: Influenza virus fusion activity toward PC-12 cells: Neutralization/reacidification experiments carried out at $37^{\circ} \mathrm{C}$. In all cases, influenza virus $(1 \mu \mathrm{g} / \mathrm{mL}$ viral protein) was added to $5 \times$ $10^{6} \mathrm{PC}-12$ cells in a final volume of $2 \mathrm{~mL}$ at $37^{\circ} \mathrm{C}$. Experiments were done either in the presence of viral prebinding (viral-cell binding allowed at $\mathrm{pH} 7.4$ for $5 \mathrm{~min}$ before the $\mathrm{pH}$ was lowered to 5.2, curves $\mathrm{a}$ and $\mathrm{b}$ ) or in its absence (fusion monitored immediately at $\mathrm{pH} 5.2$, curves $\mathrm{c}$ and $\mathrm{d}$ ). Curves a and $\mathrm{c}$ are controls. In the neutralization/ reacidification experiments (curves $b$ and $d$, done with or without binding, respectively), following a short initial period at $\mathrm{pH} 5.2$ (30 $\mathrm{s}$ for experiments with prebinding, $60 \mathrm{~s}$ for experiments without prebinding), the $\mathrm{pH}$ was raised to 7.4 (arrows up) and later reacidified back to 5.2 (arrows down).

out at $20^{\circ} \mathrm{C}$. For example, after $1 \mathrm{~min}$ of preincubation, the virus had exactly the same fusion activity as in control experiments (not shown), in sharp contrast with the results obtained in parallel experiments carried out at $37^{\circ} \mathrm{C}$. To obtain an inactivation at $20^{\circ} \mathrm{C}$ similar to that observed at 37 ${ }^{\circ} \mathrm{C}$, it was necessary to preincubate the virus at $\mathrm{pH} 5.0$ for $5 \mathrm{~min}$. Viral preincubation at $\mathrm{pH} 7.4$ in the absence of the target membrane at $37^{\circ} \mathrm{C}$ for $15 \mathrm{~min}$ had no visible effect on fusion activity (not shown).

pH Requirements during the Fusion Process. To investigate the $\mathrm{pH}$ requirements throughout the fusion process, we carried out a series of experiments in which, following the onset of fusion at $\mathrm{pH} 5.2$, the $\mathrm{pH}$ of the virus-cell mixture was temporarily raised to 7.4 and then lowered back to 5.2 (Figures 5 and 6). These experiments were performed at 20 and 37 ${ }^{\circ} \mathrm{C}$, both in the presence and in the absence of virus-cell prebinding.

In all cases, R18 dequenching was immediately arrested when the $\mathrm{pH}$ was raised to 7.4, which points to the need for continuous acidic conditions during the fusion process. It should be noted that the slow fluorescence dequenching observed upon neutralization was identical to the dequenching normally obtained at $\mathrm{pH} 7.4$ (not shown). This dequenching apparently represents slow virus-cell fusion taking place at neutral $\mathrm{pH}$ (see below). Under all experimental conditions, reacidification to $\mathrm{pH} 5.2$ resulted in the recovery of fusion activity. These results are in agreement with previous findings (Stegmann et al., 1986).

An interesting result was obtained at $37^{\circ} \mathrm{C}$. When the experiments were carried out in the presence of virus-cell prebinding, the monitored extent of dequenching (following equal times of exposure to acid) was the same both in the neutralization/reacidification experiment and in the control (Figure 5, curves a and $b$ ). In the absence of prebinding, however, the neutralization/reacidification experiment yielded lower extents of dequenching when compared to the respective control (Figure 5, curves $c$ and d). This observation implies that, in the absence of prebinding, a fraction of the viral population (most likely unbound virions) committed to the irreversible conformational change by acid exposure not only

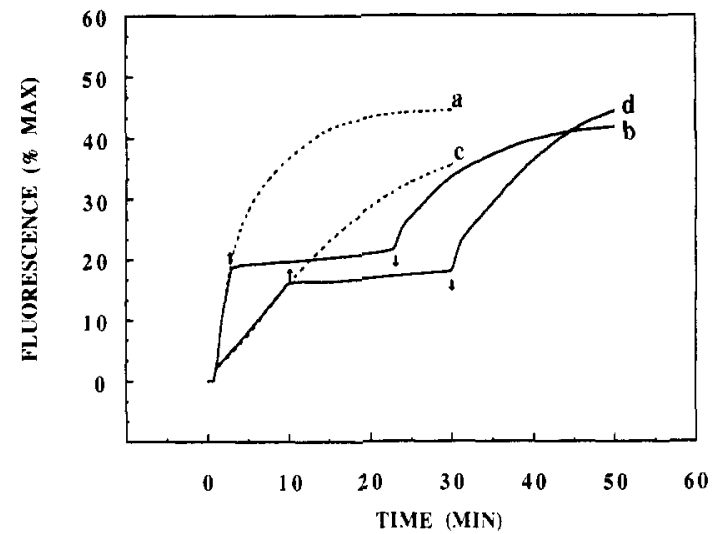

FIGURE 6: Influenza virus fusion activity toward PC-12 cells: Neutralization/reacidification experiments carried out at $20^{\circ} \mathrm{C}$. In all cases, influenza virus $(1 \mu \mathrm{g} / \mathrm{mL}$ viral protein) was added to $5 \times$ $10^{6} \mathrm{PC}-12$ cells in a final volume of $2 \mathrm{~mL}$ at $20^{\circ} \mathrm{C}$. Experiments were done either in the presence of viral prebinding (viral-cell binding allowed at $\mathrm{pH} 7.4$ for $5 \mathrm{~min}$ before the $\mathrm{pH}$ was lowered to 5.2 , curves $a$ and $b$ ) or in its absence (fusion monitored immediately at $\mathrm{pH} 5.2$, curves $\mathrm{c}$ and $\mathrm{d}$ ). Curves a and $\mathrm{c}$ are controls. In the neutralization/ reacidification experiments (curves $b$ and $d$, done with or without binding, respectively), following a short initial period at $\mathrm{pH} 5.2$ (3 $\mathrm{min}$ for experiments with prebinding, $10 \mathrm{~min}$ for experiments without prebinding), the $\mathrm{pH}$ was raised to 7.4 (arrows up) and later reacidified back to 5.2 (arrows down).

is unable to fuse following neutralization but actually is able to inactivate (Figure 5, curve d). Inspection of this curve immediately after reacidification indicates a large slope which could be due to fusion-active virions binding to the cell surface during the neutralization period. The fusion of these viral particles with target cell membranes would be triggered upon lowering the $\mathrm{pH}$ back to 5.2. With prebinding, this effect is obviously less extensive (Figure 5, compare curve b with curve d), since in this case the virus was allowed to bind to the cells (and fuse) before neutralization took place.

The interpretations presented above were prompted by the observation that influenza virus loses most of its fusion ability when preincubated at low $\mathrm{pH}$ and $37^{\circ} \mathrm{C}$ in the absence of target membranes. This inactivation process is greatly reduced at lower temperatures (Figures 3 and 4; see above). Therefore, we carried out parallel neutralization/reacidification experiments in the absence and presence of viral prebinding at 20 ${ }^{\circ} \mathrm{C}$ (Figure 6). With prebinding, the neutralization/reacidification experiment yielded the same final extent as the control (Figure 6, curves $a$ and $b$ ); in the absence of prebinding, the neutralization/reacidification experiment showed a similar extent of dequenching as the control and a faster initial rate (unlike the results observed at $37^{\circ} \mathrm{C}$, Figure 6, curves $\mathrm{c}$ and d). The results confirm the relative importance of virus-cell prebinding in protecting virions from inactivation and maintaining their fusion ability.

Fusion versus Molecular Transfer. In the application of the R18 assay to monitor fusion, it is generally assumed that dequenching, which is due to probe dilution, does not arise unless membrane mixing due to fusion has occurred. Despite demonstrations of the applicability of the assay in numerous cases (Hoekstra et al., 1984, 1985; Hoekstra \& Kok, 1989; Stegmann et al., 1990; Düzgünes et al., 1992; Lima et al., 1992), it is important to reexamine the assumption in each new system.

It is possible that probe transfer is a rare event unless the membranes are in close proximity. Consequently, experiments were designed to show whether fusion-independent probe transfer could occur from the viral envelope to the target cell plasma membrane when both membranes are in close contact. 
Table III: Effect of Viral Inactivation and Proteolytic Cleavage on the Fluorescence Increase and Cell Association of R18-Labeled Influenza Virus Incubated with PC-12 Cells ${ }^{a}$

\begin{tabular}{|c|c|c|c|c|}
\hline condn & & & & \\
\hline $\begin{array}{r}\mathrm{pH} 7.4 \\
\text { contr } \\
\text { inact } \\
\text { pH } 5.2\end{array}$ & & 100.0 & & 22.7 \\
\hline & & 00.0 & & 9.3 \\
\hline \multicolumn{5}{|c|}{$\begin{array}{l}{ }^{a} \text { For } \mathrm{pH} 7.4 \text { experiments, R18-labeled influenza virus ( } 2 \mu \mathrm{g} \text { of protein) } \\
\text { vas incubated at } \mathrm{pH} 5.0 \text { and } 37^{\circ} \mathrm{C} \text { for } 30 \text { min in the absence of target } \\
\text { ell membranes, while for } \mathrm{pH} 5.2 \text { experiments the same viral preincubation } \\
\text { ook place in the presence of proteinase } \mathrm{K} \text {. Following either treatment, } \\
\text { he virus was added to } 5 \times 10^{6} \mathrm{PC}-12 \text { cells (final volume } 2 \mathrm{~mL} \text { ), and the } \\
\text { luorescence increase was monitored as described at } 37^{\circ} \mathrm{C} \text {, either at } \mathrm{pH} \\
.4 \text { for } 15 \text { min or at } \mathrm{pH} 5.2 \text { for } 5 \text { min (preceded by } 5 \text {-min viral-cell } \\
\text { rebinding at neutral pH). In each case, the percentage of cell association } \\
\text { vas determined under the same experimental conditions, by measuring } \\
\text { he fluorescence in the supernatant (nonbound virions) and in the pellet } \\
\text { cells and bound virions) after addition of detergent as described. }{ }^{b} \text { The } \\
\text { alues obtained in several experiments ranged from } 9.8 \text { to } 12.9 \text { (\% max), } \\
\text { lways with a detectable lag of about } 2 \text { min. }\end{array}$} \\
\hline
\end{tabular}

The results obtained are presented in Table III. To examine the fluorescence dequenching at $\mathrm{pH} 7.4$, influenza virus was inactivated in the absence of the target membrane $(\mathrm{pH} 5.0$, $37^{\circ} \mathrm{C}, 30 \mathrm{~min}$ ). Following this treatment, no dequenching could be observed when the virus was added to PC- 12 cells at $\mathrm{pH} 7.4$, although, under the same conditions, its binding ability was virtually intact. Fluorescence dequenching rates of about $10 \% \max / \mathrm{h}$ have been interpreted as being due to fusion of Rous sarcoma virus with cells at neutral pH (Gilbert et al., 1990). This dequenching was inhibitable by inactivation of the virus by glutaraldehyde treatment, while in our experiments influenza virus was inactivated by pretreatment at low pH (Table III).

To determine if the slow increase in R18 fluorescence at neutral $\mathrm{pH}$ in the medium was due to fusion of the virus from within endosomes, cells were treated with agents known to prevent the acidification of the endosomal lumen, or inhibit endocytosis. Pretreatment of cells with the lysosomotropic agents $\mathrm{NH}_{4} \mathrm{Cl}$ or monensin (Mellman et al., 1986; Stegmann et al., 1987b) or the endocytosis inhibitor sodium azide (Blumenthal et al., 1987) did not affect fluorescence dequenching (not shown).

It therefore cannot be excluded that the $\mathrm{R} 18$ dequenching monitored for untreated virus at $\mathrm{pH} 7.4$, with PC-12 cells, was due to slow virus-cell fusion at neutral pH. Such fusion activity of influenza virus at neutral $\mathrm{pH}$ has been reviewed by Haywood (1988). We note that with erythrocyte ghosts (Stegmann et al., 1986; Düzgünes et al., 1992) and several other suspension cells (Düzgünes et al., 1992) we found a 3-5-fold lower fluorescence increase at neutral $\mathrm{pH}$. It might be stressed that fusion at neutral $\mathrm{pH}$ is quite slow and, therefore, the most effective route for viral entry will probably be extensive fusion with an internal acidic compartment following endocytosis. We should note, however, that systems in which the acid requirement for influenza virus activity is absolutely mandatory have also been described (Yoshimura \& Ohnishi, 1984; Stegmann et al., 1987b; Ohnishi, 1988).

Although we have shown that there is no probe transfer at $\mathrm{pH} 7.4$ in the absence of fusion, it is still possible that probe transfer does occur under acidic conditions, due to an increase in membrane hydrophobicity. Therefore, besides being inactivated as above, the virus was also pretreated with proteinase K. As shown in Table III, this treatment completely
Table IV: Fusion and Inactivation of Influenza Virus at Low Temperatures

\begin{tabular}{cclccc}
\hline $\mathrm{pH}$ & $\begin{array}{c}\text { temp } \\
\left({ }^{\circ} \mathrm{C}\right)\end{array}$ & exptl condn $^{a}$ & $\begin{array}{c}\text { fusion }^{b} \\
(\% \text { max })\end{array}$ & $\begin{array}{c}\text { binding }^{c} \\
(\% \text { max })\end{array}$ & $\begin{array}{c}\text { cell assocn }^{d} \\
(\% \text { max })\end{array}$ \\
\hline 5.2 & 4 & control & 5.2 & 53.9 & 68.0 \\
& 4 & inactivated $^{e}$ & 3.3 & 51.6 & 50.9 \\
4.0 & 4 & control & 20.3 & 53.9 & 77.5 \\
& 4 & inactivated & 13.5 & 51.6 & 77.7 \\
5.2 & 10 & control & 7.9 & 49.7 & 50.9 \\
& 10 & inactivated & 1.1 & 48.2 & 59.4 \\
\hline
\end{tabular}

${ }^{a}$ The virus was bound to $\mathrm{PC}-12$ cells for $10 \mathrm{~min}$ at $\mathrm{pH} 7.4$, and the $\mathrm{pH}$ was lowered to the indicated value. ${ }^{b}$ The extent of fusion $60 \mathrm{~min}$ after the reduction of $\mathrm{pH} .{ }^{c}$ Percent of added virus bound to cells after $10 \mathrm{~min}$ at $\mathrm{pH} 7.4{ }^{d}$ Percent of added virus bound and fused after $10 \mathrm{~min}$ at pH 7.4 and 60 min at the indicated pH. e The virus was "inactivated" for $1 \mathrm{~h}$ at $0^{\circ} \mathrm{C}$ at the indicated $\mathrm{pH}$. $f$ The virus was "inactivated" for 30 min at $\mathrm{pH} 5.2$ and $10^{\circ} \mathrm{C}$.

abolished the dequenching at $\mathrm{pH} 5.2$, while the virus still retained most of its binding ability. Under these experimental conditions, virus-cell contact was probably established via unspecific binding sites.

These results seem to indicate that, both at low and at neutral $\mathrm{pH}$, little or none of the fluorescence dequenching observed is due to nonspecific transfer from labeled influenza virions to target PC-12 membrane, thus complementing earlier control experiments ruling out probe transfer in the absence of fusion (Hoekstra et al., 1984; Düzgünes et al., 1992; Lima et al., 1992). However, the possibility that lipid mixing may not necessarily implicate the delivery of the influenza virus nucleocapsid to the cell cytoplasm may be raised. It is possible that the use of another independent fusion assay could help clarify this question.

Lack of Inactivation at $0^{\circ} \mathrm{C}$ : Real or Apparent? The observation of slow fusion of influenza virus with liposomes and erythrocyte ghosts without low-pH inactivation has been one of the focal points in the proposal of a modified model of the mechanism of fusion of this virus (Stegmann et al., 1990). The results of our analysis (Table II) enabled us to design critical experiments to reexamine this question.

Inspection of Table II indicates at 37 and $20^{\circ} \mathrm{C}$, incubating the virus alone at $\mathrm{pH} 5.0$ yields rate constants of inactivation that are similar to or somewhat larger than the values of the fusion rate constants at those temperatures. At $4^{\circ} \mathrm{C}$ and $\mathrm{pH}$ 5.2, the fusion rate constant (see Table II) is $2.7 \times 10^{-5} \mathrm{~s}^{-1}$. If $\gamma$, the inactivation rate constant (see eq 1), is of the same magnitude as $f$ or even 4 -fold larger, then the term $\exp (-\gamma t)$ in eq 1 will be close to unity for $t=30 \mathrm{~min}$ of incubation of the virus alone at $\mathrm{pH} 5.2$; consequently, no viral inactivation would be detected. This was, in fact, confirmed experimentally (not shown). It should be emphasized that, according to eq 1 and 3 , inactivation does not require a very long lag phase, but it will be hard to notice its existence after 30 min of viral incubation at pH 5.2 and $4^{\circ} \mathrm{C}$, since its action is only exhibited by a reduction in its fusion rate constant. When the fraction of virus fused is small, it is hard to resolve whether fusion inactivation has occurred.

In order to examine whether inactivation of the virus at low $\mathrm{pH}$ does occur at $0^{\circ} \mathrm{C}$, we extended the time of incubation of the virus alone to $60 \mathrm{~min}$ and, in addition, looked at the results of fusion and inactivation at $\mathrm{pH} 4.0$, where the values of $f$ and $\gamma$ are larger than at pH 5.0. The results are presented in Table IV. At pH 4.0 and $4^{\circ} \mathrm{C}$, the difference in fusion between the inactivated virus and the control is appreciable, but even at pH 5.2, the effect of inactivation is noticeable. At $10^{\circ} \mathrm{C}$ and $\mathrm{pH} 5.2$, it is sufficient to preincubate the virus alone for $30 \mathrm{~min}$ in order to observe a significant decrease in 
Table V: Fusion and Inactivation Rate Constants for Influenza Virus Preincubated without Cells at Low $\mathrm{pH}^{a}$

\begin{tabular}{cllc}
\hline temp $\left({ }^{\circ} \mathrm{C}\right)$ & $\mathrm{pH}$ & \multicolumn{1}{c}{$f\left(\mathrm{~s}^{-1}\right)$} & $\gamma\left(\mathrm{s}^{-1}\right)$ \\
\hline $37^{b}$ & 5.0 & 0.03 & 0.046 \\
$20^{b}$ & 5.0 & $1.5 \times 10^{-3}$ & $6 \times 10^{-3}$ \\
$4 / 0^{c, d}$ & 5.0 & $2.4 \times 10^{-5}$ & $10^{-4}$ \\
$4 / 0^{c, d}$ & 4.0 & $9.7 \times 10^{-5}$ & $1.5 \times 10^{-4}$ \\
\hline
\end{tabular}

${ }^{a}$ The uncertainties in the parameters $f$ and $\gamma$ at 37 and $20^{\circ} \mathrm{C}$ are indicated in Table II. At $4^{\circ} \mathrm{C}$, the uncertainty in $f$ is smaller $(20 \%)$, but the uncertainty in $\gamma$ is about $60 \%,{ }^{b}$ Values taken from Table II. c Experimental conditions as in Table IV. The parameters determined were based on experimental values given in Table IV. "Inactivation" carried out at $0^{\circ} \mathrm{C}$, fusion monitored at $4^{\circ} \mathrm{C}$.

fusion activity. The results of the analysis of these cases are summarized in Table V, where the values at 37 and $20^{\circ} \mathrm{C}$ are also included. Clearly, both $f$ and $\gamma$ decrease upon lowering the temperature from 37 to $4^{\circ} \mathrm{C}(f)$ or $0^{\circ} \mathrm{C}(\gamma)$, but low-pH inactivation does exist at $0^{\circ} \mathrm{C}$.

\section{DISCUSSION}

The combination of cell association measurements with two types of fusion experiments, i.e., with or without prebinding, enabled us to elucidate the details of the effect of $\mathrm{pH}$ on virus binding to and fusion with plasma membranes. In both cases, the mass-action kinetic model employed could yield good simulations and predictions for the kinetics of fusion of influenza virus, strain $\mathrm{A} / \mathrm{PR} / 8 / 34$, with PC-12 cells.

While the $\mathrm{pH}$ optimum of the fusion activity of influenza virus may depend on the strain of the virus and on the type of target membrane, for several different viral strains the $\mathrm{pH}$ optimum of fusion is generally considered to be about 5 (Stegmann et al., 1986; Morris et al., 1989; Sarkar et al., 1989; Düzgünes et al., 1992). The results in Tables I and II demonstrate, however, that the fusion rate constant is, in fact, larger at $\mathrm{pH} 4.0$ or 4.5 than at $\mathrm{pH}$ 5.2. On the other hand, the binding capacity of the virus as determined by total virus association with the cells or by the forward rate adhesion constant, $C$ (Table I), is much less sensitive to $\mathrm{pH}$.

Our results indicate that the dependence of the fusion rate on $\mathrm{pH}$ might be obscured by the process of inactivation of the virus, whose rate also increases upon lowering the $\mathrm{pH}$ (see Tables I and II). Thus, when the virus is added directly to the cells at low $\mathrm{pH}$, a large portion of viral fusion activity is diminished by the time the virus has established contact with the cell plasma membrane. This leads to the apparent optimal fusion activity at $\mathrm{pH} 5.2$ (Figure 1). On the other hand, following prebinding of the virus to the cells at neutral $\mathrm{pH}$, where no inactivation of the virus occurs, the initial rate of fusion for $\mathrm{pH} 4.5$ is severalfold larger than that at $\mathrm{pH} 5.2$ (see Figure 2). Several minutes after the $\mathrm{pH}$ is lowered, the extent of fusion at $\mathrm{pH} 5.2$ exceeds that at $\mathrm{pH} 4.5$, due the faster inactivation that occurs at this lower $\mathrm{pH}$; however, by that time, most of the prebound virus has already fused. At $4^{\circ} \mathrm{C}$, where the rate of inactivation is slow, the results in Table IV demonstrate a 4-fold larger extent of fusion at $\mathrm{pH} 4.0$ than at $\mathrm{pH}$ 5.2.

The question is whether this trend of $\mathrm{pH}$ dependence would be observed with other target membranes. The significant drop in fusion activity at $\mathrm{pH}$ values above 5.0 is commonly observed. The increase in the fusion rate constant at $\mathrm{pH}$ values below 5.0 was noted previously for this strain of virus fusing with HL-60 and other suspension cells (Düzgünes et al., 1992), but with PC-12 cells, the pattern is more extreme. This comparison also suggests that the $\mathrm{pH}$ dependence of the viral fusion activity is not merely a reflection of the conformational changes occurring in the HA glycoprotein, but also depends on the response of the components of the target membranes to $\mathrm{pH}$ changes, and the interaction of these components with the HA. The range found here at $37^{\circ} \mathrm{C}$ and $\mathrm{pH} 5.2$ for the fusion rate constant, $0.03-0.07 \mathrm{~s}^{-1}$, is somewhat higher than the average values determined for fusion with suspension cells (Nir et al., 1990; Düzgünes et al., 1992), but it is still within the range of values found previously $\left(0.01-0.1 \mathrm{~s}^{-1}\right)$. These values are severalfold smaller than the values found for liposomes of a variety of compositions, and an order of magnitude below the value found for cardiolipin liposomes (Nir et al., 1986a, 1988; Stegmann et al., 1989).

Our results of low-pH inactivation of influenza virus, strain $\mathrm{A} / \mathrm{PR} / 8 / 34$, fusing with $\mathrm{PC}-12$ cells are essentially similar to those found for this strain fusing with erythrocyte ghosts, and for other strains fusing with erythrocyte ghosts or liposomes (Nir et al., 1990; Düzgünes et al., 1992; Stegmann et al., 1987a, 1989). In contrast, the fusion activity of this strain toward HL-60 and CEM cells was only mildly reduced following $20 \mathrm{~min}$ of incubation of the virus alone at $\mathrm{pH} 5.0$ and $37^{\circ} \mathrm{C}$ (Düzgünes et al., 1992). Hence, it is likely that different mechanisms operate in the fusion of this virus with the two types of cellular plasma membranes. It is also possible that the interaction of the viral glycoproteins with the plasma membrane ligands of HL- 60 cels results in a reversal of viral inactivation. Viral inactivation has been proposed to be due to clustering of the envelope glycoproteins upon lowering the $\mathrm{pH}$ (Junankar \& Cherry, 1986). Thus, the reversal of viral inactivation may be brought about via partial dissociation of the preformed clusters by certain membrane ligands in HL60 , but not in PC- 12 cells. On the other hand, our results demonstrate that the virions bound to the cell surface are also inactivated to some extent by low $\mathrm{pH}$. The rate constant of inactivation at $\mathrm{pH} 5.0$ for the virus prebound to $\mathrm{PC}-12$ cells is similar to that found for erythrocyte ghosts and several cell lines (Nir et al., 1990; Düzgünes et al., 1992). The rate constants of inactivation of the bound virus are about half the values for the virus alone (see Tables I and II).

The effect of temperature on viral fusion activity is dramatic. The fusion rate constant is decreased by 20 - and 1000 -fold, respectively, when the temperature is reduced from $37^{\circ} \mathrm{C}$ to 20 or $4{ }^{\circ} \mathrm{C}$. The reduction in temperature also causes an increase in the lag time from $0-1 \mathrm{~s} \mathrm{at} 37^{\circ} \mathrm{C}$ to $300 \mathrm{~s}$ at $4^{\circ} \mathrm{C}$, comparable to previous observations with erythrocyte ghosts and liposomes as target membranes (Stegmann et al., 1990). We only refer to the lag time found for prebound virus, since the delay due to binding can result in longer apparent lag times. Viral association with the cells is not affected significantly by temperature, due to a combination of factors. The increase with temperature of the adhesion rate constant $C$ is less steep than the dissociation rate constant $D$ (Nir et al., 1983), but there is also irreversible association due to fusion, whose rate increases with temperature. A reduction in temperatue also results in dramatic decrease in the rate of low-pH inactivation.

The first step in the fusion of prebound influenza virus appears to be the exposure of the HA2 $\mathrm{N}$-terminal fusion peptides (White \& Wilson, 1987). Stegmann et al. (1990) have found that, at $0^{\circ} \mathrm{C}$ and $\mathrm{pH} 5.0$, and following prebinding, the virus can fuse with zwitterionic liposomes without the unfolding of the HA trimers. They have proposed that the lag time of fusion reflects the time needed for lateral movement and reorganization of the HA molecules in the zone of contact with the target membrane. This proposal is in accord with 
previous suggestions that HA-mediated fusion requires more than one trimer (Doms \& Helenius, 1986; Ellens et al., 1990). On the basis of experiments where fusion at $0^{\circ} \mathrm{C}$ was not arrested following neutralization of the $\mathrm{pH}$, these authors have suggested that, while the reactions that lead up to the fusioncompetent complex are dependent on low $\mathrm{pH}$, the final fusion event itself is not. However, our neutralization experiments at $37^{\circ} \mathrm{C}$ (Figure 5), and even at $20^{\circ} \mathrm{C}$ (Figure 6), demonstrate that fusion is essentially arrested upon neutralization, as previously noted (Stegmann et al., 1986). We propose that, at 37 or $20^{\circ} \mathrm{C}$, neutralization leads to rapid dissociation of the oligomeric fusion complex, probably due to repulsion between adjacent charged amino acids at neutral pH. At 0 or $4{ }^{\circ} \mathrm{C}$, however the rate of dissociation is generally very slow (Nir et al., 1983). Hence, the fusion complex, whose formation in the cold is also very slow, remains undissociated for very long periods. A sequence of events analogous to the HA fusion complex is observed with an amphipathic synthetic peptide, GALA, which, like the HA2 fusion peptide, binds rapidly to zwitterionic liposomes at $\mathrm{pH} 5.0$ but not at neutral $\mathrm{pH}$ (Parente et al., 1990). Following binding, the peptides aggregate within the membrane and form pores that enable fast and sizeselective leakage of molecules. Upon neutralization, leakage is arrested instantaneously, and the peptides dissociate from the membrane.

Stegmann et al. (1990) demonstrated slow fusion of influenza virus at $\mathrm{pH} 5.0$ and $0^{\circ} \mathrm{C}$ without dissociation of the tops of the ectodomain of the HA trimer. They suggested that the dissociation of the tops of the HA trimer at $37^{\circ} \mathrm{C}$ is associated with viral inactivation. This proposal was based on the lack of apparent inactivation at $0^{\circ} \mathrm{C}$, and the authors did not consider differences between the lag phases for fusion and inactivation.

Our results require reconsideration of these conclusions, because we do find slow inactivation of the virus at all temperatures down to $0^{\circ} \mathrm{C}$ (see Tables IV and V). In addition, we cannot rule out the importance of unfolding of the tops of the HA trimers in the fusion process. The fusion rate constant at $37^{\circ} \mathrm{C}$ (at which temperature unfolding occurs; Stegmann et al., 1990) is 1000-fold larger than at $4^{\circ} \mathrm{C}$ (at which temperature unfolding was not observed: Stegmann et al., 1990). This comparison could mean that the mechanism of fusion at 4 or $0^{\circ} \mathrm{C}$ is different from the physiological one at $37^{\circ} \mathrm{C}$. While we do not have evidence for the involvement of the HA tops in the fusion process, it is clear that lack of their unfolding does not affect virus binding to the cells, a process which is also insensitive to $\mathrm{pH}$. If the unfolding of the HA tops plays a role in viral inactivation, then our results would imply that a slow process of such unfolding does occur even at $0^{\circ} \mathrm{C}$. It should be stressed that recent studies have indeed revealed that some unfolding of the HA globular head does occur at $0^{\circ} \mathrm{C}$ (J. White, personal communication), possibly indicating that fusion and inactivation may involve common molecular rearrangements. The results of Stegmann et al. (1990) demonstrate, however, that the exposure of the HA2 fusion peptide at low $\mathrm{pH}$ is not the rate-limiting step in fusion and that the exposure can occur at $0^{\circ} \mathrm{C}$ without the unfolding of HA tops. Recently, Kemble et al (1992) suggested that partial dissociation of the globular head domains was required for optimal membrane fusion activity of HA (X:31 strain). Clearly, molecular rearrangements in addition to the exposure of the fusion peptide are necessary. It was proposed previously that fusion is mediated by the process of conformational change of the $\mathrm{HA}$ when the $\mathrm{pH}$ is lowered, and not by the final equilibrium conformation of the protein at low pH (Düzgünes \& Gambale, 1988).

Overall, our results demonstrate that, at temperatures and $\mathrm{pH}$ values where the fusion rate constants are large, the inactivation rate constants are also large, and vice versa. This may be an indication that the rate-limiting step in the sequence of fusion events culminating in membrane merging depends on the same process that leads to inactivation. We favor the view that the rate-limiting step in the fusion of prebound influenza virus is association and arrangement of the HA trimers interacting with the target membranes, in agreement with other studies (Doms \& Helenius, 1986; Sarkar et al., 1989; Ellens et al., 1990; Stegmann et al., 1990). At lower $\mathrm{pH}$, e.g., $\mathrm{pH} 4.0$, this process is faster. In the absence of target membranes, HA association (at low $\mathrm{pH}$ ) results in inactivation at a rate dependent on $\mathrm{pH}$ and temperature. For the virus bound to certain target membranes (erythrocyte ghosts, PC-12 cells), the process of inactivation exists, albeit at a slower rate compared to inactivation of the virus alone. With other types of target cells, however, such as HL-60 and CEM cells, it is possible that the fusion activity of the "inactivated" (i.e., low $\mathrm{pH}$ pretreated) virus is partially restored (Düzgünes et al., 1992).

\section{ACKNOWLEDGMENT}

We thank Dr. J. Sedat (UCSF) for providing access to the VAX computer.

\section{REFERENCES}

Blumenthal, R., Bali-Puri, A., Walter, A., Covell, D., \& Eidelman, O. (1987) J. Biol. Chem. 262, 13614-13619.

Brunner, J., Zugliani, C., \& Mischler, R. (1991) Biochemistry 30, 2432-2438.

Doms, R. W., \& Helenius, A. (1986) J. Virol. 60, 833-839.

Doms, R. W., Helenius, A., \& White, J. (1985) J. Biol. Chem. 260, 2973-2981.

Düzgünes, N., \& Gambale, F. (1988) FEBS Lett. 227, 110-114.

Düzgünes, N., Lima, M. C. P., Stamatatos, L., Flasher, D., Alford, D., Friend, D. S., \& Nir, S. (1992) J. Gen. Virol. 73, 27-37.

Ellens, H., Bentz, J., Mason, D., Zhang, F., \& White, J. (1990) Biochemistry 29, 9697-9707.

Gilbert, J. M., Mason, D., \& White, J. M. (1990) J. Virol. 64, 5106-5113.

Haywood, A. M. (1988) in Molecular Mechanisms of Membrane Fusion (Ohki, S., Doyle, D., Flanagan, T. D., Hui, S. W., \& Mayhew, E., Eds.) pp 427-440, Plenum Press, New York.

Hoekstra, D., \& Kok, J. W. (1989) Biosci. Rep. 9, 273-305.

Hoekstra, D., DeBoer, T., Klappe, K., \& Wilschut, J. (1984) Biochemistry 23, 5675-5681.

Hoekstra, D., Klappe, K., DeBoer, T., \& Wilschut, J. (1985) Biochemistry 24, 4739-4745.

Junankar, P. R., \& Cherry, R. J. (1986) Biochim. Biophys. Acta 854, 198-206.

Kemble, G. W., Bodian, D. L., Rosé, J., Wilson, I. A., \& White, J. M. (1992) J. Virol. 66, 4940-4950.

Lima, M. C. P., Ramalho-Santos, J., Martins, M. F., Carvalho, A. P., Bairos, V. A., \& Nir, S. (1992) Eur. J. Biochem. 205, 181-186.

Marsh, M., \& Helenius, A. (1989) Adv. Virus Res. 36, 107-151.

Mellman, I., Fuchs, R., \& Helenius, A. (1986) Annu. Rev. Biochem. 55, 663-700.

Morris, S. J., Sarkar, D. P., White, J. M., \& Blumenthal, R. (1989) J. Biol. Chem. 264, 3972-3978.

Nir, S., Bentz, J., Wilschut, J., \& Düzgünes, N. (1983) Prog. Surf. Sci. 13, 1-124. 
Nir, S., Stegmann, T., \& Wilschut, J. (1986a) Biochemistry 25, 257-266.

Nir, S., Klappe, K., \& Hoekstra, D. (1986b) Biochemistry 25, 2155-2161.

Nir, S., Stegmann, T., Hoekstra, D., \& Wilschut, J. (1988) in Molecular Mechanisms of Membrane Fusion (Ohki, S., Doyle, D., Flanagan, T. D., Hui, S. W., \& Mayhew, E., Eds.) pp 451-465, Plenum Press, New York.

Nir, D., Düzgünes, N., Lima, M. C. P., \& Hoekstra, D. (1990) Cell Biophys. 17, 181-201.

Ohnishi, S.-I. (1988) Curr. Top. Membr. Transp. 32, 257-296.

Parente, R. A., Nir, S., \& Szoka, F. C., Jr. (1990) Biochemistry $29,8720-8728$.

Ruigrok, R. W. H., Wrigley, N. G., Calder, L. J., Cusack, S., Wharton, S. A., Brown, E. B., \& Skehel, J. J. (1986) EMBO J. 5, 41-49.

Sarkar, D. P., Morris, S. J., Eidelman, O., Zimmerberg, J., \& Blumenthal, R. (1989) J. Cell Biol. 199, 113-122.

Sato, S. B., Kawasaki, K., \& Ohnishi, S. (1983) Proc. Natl. Acad. Sci. U.S.A. 80, 3153-3157.
Skehel, J. J., Bayley, P. M., Brown, E. B., Martin, S. R., Waterfield, M. D., White, J. M., Wilson, I. A., \& Wiley, D. C. (1982) Proc. Natl. Acad. Sci. U.S.A. 79, 968-972.

Stegmann, T., Hoekstra, D., Scherphof, G., \& Wilschut, J. (1986) J. Biol. Chem. 261, 10966-10969.

Stegmann, T., Booy, F. P., \& Wilschut, J. (1987a) J. Biol. Chem. $262,17744-17749$.

Stegmann, T., Morselt, H. W. M., Booy, F. P., Sholma, J., \& Wilschut, J (1987b) Biochim. Biophys. Acta 904, 165-170.

Stegmann, T., Nir, S., \& Wilschut, J. (1989) Biochemistry 28, 1698-1704.

Stegmann, T., White, J., \& Helenius, A. (1990) EMBO J. 9, 4231-4241.

Wharton, S. A., Skehel, J. J., \& Wiley, D. C. (1986) Virology $149,27-35$.

White, J. (1990) Annu. Rev. Physiol. 52, 675-697.

White, J. M., \& Wilson, I. A. (1987) J. Cell Biol. 105, 28872896.

Yoshimura, A., \& Ohnishi, S.-I. (1984) J. Virol. 51, 489-496. 